\title{
Characterization of the chromosomes of Bacillus subtilis merodiploid strains by quantitative DNA-DNA hybridization
}

\author{
Philippe M. Hausert and Dimitri Karamata \\ Author for correspondence: Dimitri Karamata. Tel: +41213206075. Fax: +41213206078.
}

Institut de Génétique et Biologie Microbiennes, Rue César-Roux 19, 1005 Lausanne, Switzerland

\begin{abstract}
The position of junctions and the extent of the duplicated chromosomal regions in Bacillus subtilis merodiploid strains were studied by quantitative DNA-DNA hybridization. We describe a method which allows (i) the identification of genes present in two copies per chromosome and (ii) the measurement of the amount of additional DNA in chromosomes with relatively large duplicated regions (about $10 \%$ or more). Analysis of previously described B. subtilis merodiploid strains GSY1127, GSY1800 and GSY1835 revealed that the duplicated segments represent $29 \pm 2 \%, 7 \pm 2 \%$ and $13 \pm 2 \%$ of the chromosome, respectively. Small discrepancies between these and previous genetic linkage data are discussed. Support for a role of prophage SP $\beta$ in the formation of merodiploid GSY1835 is provided. In conclusion, the described method confirmed the genetic maps of the merodiploids previously obtained by transduction and transformation crosses and showed that a duplication of a segment is not accompanied by large deletions of other chromosomal regions, providing direct evidence that a cell can accommodate genomes of substantially increased size.
\end{abstract}

Keywords: Bacillus subtilis, merodiploids, chromosome size, prophage SP $\beta$

\section{INTRODUCTION}

In bacteria, the presence of additional DNA, either plasmidic or a duplication of a chromosomal region, is frequently accompanied by reduced growth rate of the cells. In the absence of any selective pressure, additional DNA is often lost, as if the cell tends to restore a normal $\mathrm{DNA}$ /volume ratio, which apparently ensures the highest growth rate. For instance, it was recently shown that Bacillus subtilis cells are unable to accommodate two complete chromosomes; multiple chromosomal copies, present in fused protoplasts, are segregated in separate cells at the time of cell wall regeneration (Hauser \& Karamata, 1992). Therefore, assuming that a cell tends to restore an optimal DNA/volume ratio, it is conceivable that diploidy of a given region could be compensated by deletion(s) in other, possibly non-essential, regions of the chromosome. The existence of $B$. subtilis merodiploid strains, shown to contain diploid regions of up to $29 \%$ of the genome (Anagnostopoulos, 1990; see below), offers a possibility to test his hypothesis by comparing the

†Present address: Sir William Dunn School of Pathology, Chemical Pathology Unit, University of Oxford, South Parks Road, Oxford OX1 3RE, UK. chromosomal size of merodiploid to haploid cells by physical methods.

We report a method, based on DNA-DNA hybridization, which allows accurate determination of the size of merodiploid chromosomes and the identification of markers present in two copies. The results presented show unambiguously that duplicated regions correspond to additional DNA. They largely confirm the size of the duplicated regions obtained by genetic linkage (Anagnostopoulos, 1990).

\section{METHODS}

Bacterial strains, plasmids and bacteriophages. These are listed in Table 1. All recombinant plasmids and bacteriophages contain chromosomal fragments of strains isogenic to B. subtilis 168.

Media, growth conditions and strain conservation. Rich SA medium and minimal medium $\mathrm{S}$ were as described by Karamata \& Gross (1970). SR, the complex medium of Schaeffer $e t$ al. (1965), supplemented with $20 \mu \mathrm{g}$ thymidine $\mathrm{ml}^{-1}$ and solidified with Gibco agar $(1 \cdot 2 \%, \mathrm{w} / \mathrm{v})$, was used for strain conservation after sporulation at $30^{\circ} \mathrm{C}$. For conservation of the merodiploid strain GSY1127, cells growing exponentially in minimal medium $\mathrm{S}$ were supplemented with glycerol $(15 \%, \mathrm{v} / \mathrm{v})$ and stored 
Table 1. Bacterial strains, plasmids and bacteriophages

\begin{tabular}{|c|c|c|}
\hline $\begin{array}{l}\text { Strain, plasmid } \\
\text { or bacteriophage }\end{array}$ & Genotype or description & Source, reference or remarks \\
\hline \multicolumn{3}{|l|}{ Bacillus subtilis } \\
\hline L1440 & Prototroph & Mauël \& Karamata (1984) \\
\hline GSY1269 & $\operatorname{trpE} 26$ ilvC1 & Trowsdale \& Anagnostopoulos (1975) \\
\hline GSY1127 & bisH2 ilvC1/ilv $C^{+}$ & Anagnostopoulos \& Trowsdale (1976) \\
\hline GSY1800 & $\operatorname{trpE} 26$ bisH2 $\operatorname{tyr} A^{+} / \operatorname{trp} E 26^{+}$bis $H^{+} \operatorname{tyr} A 1$ & Schneider et al. (1982) \\
\hline GSY1835 & $\operatorname{trp} E 30$ & Schneider \& Anagnostopoulos (1981) \\
\hline \multicolumn{3}{|l|}{ Plasmids } \\
\hline pPRTR1 & $\begin{array}{l}\text { PJH101 with a } 0.7 \mathrm{~kb} \text { insert carrying gene } \operatorname{degR} \\
\text { (formerly prtR) }\end{array}$ & 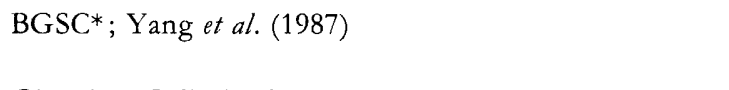 \\
\hline pUF7-5 & pJH101 with a $1.7 \mathrm{~kb}$ insert from the fla $A$ locus & $\begin{array}{l}\text { Gianni \& Galizzi (1986); out I was shown to correspond } \\
\text { to the fla A locus (Albertini et al., 1991; Hauser et al., } \\
\text { 1991) }\end{array}$ \\
\hline $\mathrm{pMP} 33 / 25$ & pJH101 with a $4.5 \mathrm{~kb}$ insert carrying gene $d n a B$ & $\begin{array}{l}\text { A. Galizzi, Università di Pavia, Italy; Ogasawara et al. } \\
\text { (1986) }\end{array}$ \\
\hline pMP60/13 & $\begin{array}{l}\text { pJH101 with a } 11 \mathrm{~kb} \text { insert carrying gene dnaN } \\
\text { (formerly } d n a G \text { ) }\end{array}$ & Perego et al. (1987) \\
\hline pO.P & pBR322 with a $3.6 \mathrm{~kb}$ carrying gene out $B$ & Ferrari et al. (1985b) \\
\hline pSU12 & $\begin{array}{l}\text { pBR322 with a } 9 \cdot 5 \mathrm{~kb} \text { insert carrying gene } b s d M \\
\text { (formerly } h s r M \text { ) }\end{array}$ & Kiss et al. (1985) \\
\hline pTRP-H3B2† & $\begin{array}{l}\text { pBR322 with a } 2 \cdot 2 \mathrm{~kb} \text { insert carrying genes } \operatorname{trp} E \text { and } \\
\operatorname{trpD}\end{array}$ & $\begin{array}{l}\text { BGSC*; Band et al. (1984); the } 2.9 \mathrm{~kb} \text { fragment from } \\
\text { the EcoRV site of the insert the most distant from } \\
\text { gene } \operatorname{trp} D \text { to the } P v u I I \text { site of the vector was used as } \\
\text { probe for gene } \operatorname{trp} E\end{array}$ \\
\hline p'TRPD & pMTL20EC with a $0.9 \mathrm{~kb}$ insert carrying gene $\operatorname{tr} p D$ & $\begin{array}{l}\text { This work; the } 0.9 \mathrm{~kb} \text { fragment of plasmid pTRP-H3B2 } \\
\text { from the } P \nu u I I \text { site of the insert to the } S p b \mathrm{I} \text { site of the } \\
\text { vector was subcloned and used as probe for gene } \operatorname{trpD}\end{array}$ \\
\hline pBD54 & pBR322 with a $5.2 \mathrm{~kb}$ insert carrying gene $\cot A$ & Donovan et al. (1987) \\
\hline pphe $^{+} 1$ & $\begin{array}{l}\text { pMTL20EC with a } 1.4 \mathrm{~kb} \text { insert carrying gene } p h e B \text { and } \\
\text { part of gene phe } A\end{array}$ & Hauser \& Karamata (1992) \\
\hline p8104 & $\begin{array}{l}\text { pMTL20EC with a } 1.5 \mathrm{~kb} \text { insert from the region of } \\
\text { gene } \operatorname{tag} B\end{array}$ & Young et al. (1989); fragment J \\
\hline $\mathrm{pC} 8$ & $\begin{array}{l}\text { pMTL20EC with a } 1.4 \mathrm{~kb} \text { insert from prophage PBSX } \\
\text { genome }\end{array}$ & Longchamp (1990) \\
\hline pDALsub1 & pBS42 with a $1.8 \mathrm{~kb}$ insert carrying gene dal & BGSC*; Ferrari et al. (1985a) \\
\hline pFM1 & pBR325 with a $6 \mathrm{~kb}$ insert carrying gene $p u r M$ & Saxild \& Nygaard (1988) \\
\hline pLUM20 & $\begin{array}{l}\text { pHV32 with a } 3.2 \mathrm{~kb} \text { insert carrying genes } g l p D \text { and } \\
g l p K\end{array}$ & Holmberg \& Rutberg (1989) \\
\hline pUC12sspE & pUC12 with a $1.2 \mathrm{~kb}$ insert carrying gene $s s p E$ & Hackett \& Setlow (1987) \\
\hline PРAT83 & pJAB1 with a $1.8 \mathrm{~kb}$ insert carrying gene spoIIE & Collins et al. (1985) \\
\hline \multicolumn{3}{|l|}{ Bacteriophages } \\
\hline$\lambda \mathrm{C} 4 \mathrm{BsF} 14$ & $\lambda$ Charon $4 \mathrm{~A}$ with a $13.3 \mathrm{~kb}$ insert carrying gene dna $C$ & Perego et al. (1987) \\
\hline$i 970$ & $\begin{array}{l}\lambda \text { Charon } 4 \mathrm{~A} \text { with a } 17 \mathrm{~kb} \text { insert from prophage } \mathrm{SP} \beta \\
\text { genome }\end{array}$ & $\begin{array}{l}\text { M. G. Sargent; isolated from the DNA bank of Ferrari } \\
\text { et al. (1981) }\end{array}$ \\
\hline 2378 & $\begin{array}{l}\lambda \text { Charon } 4 \mathrm{~A} \text { with a } 16 \mathrm{~kb} \text { insert from prophage } \mathrm{SP} \beta \\
\text { genome }\end{array}$ & $\begin{array}{l}\text { As for } \lambda 970 ; \text { the fragment of prophage } \mathrm{SP} \beta \text { present in } \\
\text { this phage shows no overlap with that present in } \\
\text { phage } \lambda 970\end{array}$ \\
\hline
\end{tabular}

* Bacillus Genetic Stock Center, Ohio State University, Columbus, Ohio, USA.

† The $\operatorname{trpE}$ and $\operatorname{trpD}$ genes present on this plasmid were found to be those of strain 168. Band et al. (1984) raised the possibility that the trp genes of the sequenced W168 strain derive from W23. However, Southern experiments with strain W168 trp genes as probes and strain 168 chromosomal DNA (results not presented) revealed that in strain W168 only part of gene trpC derives from W23. 
at $-80^{\circ} \mathrm{C}$ after being frozen in liquid nitrogen. When required, media were supplemented with $20 \mu \mathrm{g} \mathrm{ml}^{-1}$ of amino acids.

Quantitative DNA-DNA hybridization. Chromosomal DNA was prepared from stationary-phase cultures (about $3 \times 10^{8}$ cells $\mathrm{ml}^{-1}$, at least $3 \mathrm{~h}$ after the end of the exponential phase), grown in SA medium at $37^{\circ} \mathrm{C}$. Following extraction (Marmur, 1961), DNA was purified on a $\mathrm{CsCl}$ density gradient (Maniatis et al., 1982), measured by the diphenylamine method, and stored at $-80^{\circ} \mathrm{C}$. Plasmid and bacteriophage DNA were prepared as described by Del Sal et al. (1988) and Grossberger (1987), respectively. Radioactive probes were synthesized by the random priming method (Feinberg \& Vogelstein, 1983), i.e. restriction fragments corresponding to $B$. subtilis DNA inserts, purified by a Geneclean kit (supplied by Lucerna Chem, Switzerland), were labelled with $5^{\prime}-\left[\alpha_{-}{ }^{32} \mathrm{P}\right]$ deoxyadenosine triphosphate (3000 Ci mmol ${ }^{-1}, 111 \mathrm{TBq} \mathrm{mmol}^{-1}$; Amersham). Quantitative hybridization was performed as described by Young et al. (1989). For each strain to be probed, DNA samples of $0.05,0.15$ and $0.5 \mu \mathrm{g}$ were adsorbed onto filters. Probes were generated from cloned fragments of different strain 168 derivatives and used at the highest concentration. After hybridization, filters were washed three times in $2 \times$ SSC $/ 0.1 \%$ SDS for $10 \mathrm{~min}$ at room temperature, once in $0.5 \times \mathrm{SSC} / 0.1 \% \mathrm{SDS}$ for $60-90 \mathrm{~min}$ at $65^{\circ} \mathrm{C}$, and their radioactivity measured. The saturation of the samples by probe DNA was assessed by the proportionality of the hybridization counts to the quantity of adsorbed DNA. Since in some instances $0.5 \mu \mathrm{g}$ samples were not saturated, counts obtained from the $0.15 \mu \mathrm{g}$ samples, providing higher and thus more accurate counts than the $0.05 \mu \mathrm{g}$ samples, were used throughout this study (see Table 2).

\section{RESULTS AND DISCUSSION}

\section{Description of the system and theoretical correlation between the size of the duplicated region and quantitative hybridization counts}

The experiments were performed on merodiploid strains GSY1127, GSY1800 and GSY1835 of B. subtilis (Fig. 1), shown by genetic linkage to contain duplicated regions corresponding to $25 \%, 4 \%$ and $7 \%$ of the genome (Anagnostopoulos, 1990). They were obtained by transformation crosses between strains with the chromosomal structure of strain 168 and those carrying chromosomal rearrangements associated with the $\operatorname{tr} p E 26$ mutation, i.e. translocation of segment $\mathrm{C}$ of the chromosome, involving disruption of the $\operatorname{tr} p E$ gene, and inversion of the segment A-I flanking the replication origin (Audit \& Anagnostopoulos, 1972; Anagnostopoulos \& Trowsdale, 1976; Schneider \& Anagnostopoulos, 1981; Anagnostopoulos, 1977; Schneider et al., 1982). The genetic maps of merodiploid strains presented in Fig. 1 were deduced by the latter authors from transduction and transformation linkages.

Duplication of a chromosomal fragment corresponding to $x \%$ of the haploid genome (relative size $=100$ ) leads to a merodiploid cell whose relative chromosome size is $100+x$. The number of such chromosomes per unit weight of DNA is reduced by $100 /(100+x)$ compared to the number of haploid chromosomes. Therefore, when a given probe is hybridized to a unit weight of merodiploid DNA, the number of counts obtained will not only depend on the chromosomal localization of the probe (haploid or diploid region), but also on the size $(x)$ of the duplicated segment. The ratios of hybridization counts obtained with haploid to those obtained with merodiploid DNA will be $R_{1}=(100+x) / 100$ or $R_{2}=0 \cdot 5 \cdot(100+x) /$ 100 for genes present in one or two copies in the merodiploid chromosome, respectively. Thus, the relative size $(x)$ of the duplicated fragment can be calculated from hybridization counts ratios as follows:

$x=100\left(R_{1}-1\right)=100\left(2 R_{2}-1\right)$

\section{Determination of the size of duplicated regions in merodiploid strains and the identification of specific genetic markers present in two copies}

DNA preparations were obtained from stationary-phase cultures of haploid strains L1440 and GSY1269, and merodiploid strains GSY1127, GSY1800 and GSY1835, and their concentration determined by the diphenylamine method. A $0 \cdot 15 \mu \mathrm{g}$ sample of each DNA preparation, adsorbed on filters, was hybridized with radioactive probes at a saturating concentration (see Methods). The probes were obtained from clones whose map positions, previously ascertained by physical mapping (not presented), are distributed relatively uniformly around the chromosome (Fig. 1). For all the probes shown in Table 2 , the ratio between counts obtained with the relevant haploid strain and the merodiploid strains was calculated. In addition, these ratios were obtained (not presented) for a further 28 probes arbitrarily chosen from a DNA library of strain 168 (Mauël et al., 1989). For each merodiploid strain, the mean of the ratios obtained with all probes present in one $\left(R_{1}\right)$ or in two copies $\left(R_{2}\right)$, with the exception of $\operatorname{trp} D$ and $\operatorname{trp} E$ (see below), were introduced into equation (1) derived here above. The calculation provides the size of the duplicated region, i.e. the additional DNA in merodiploid strains GSY1127, GSY1800 and GSY1835, which amounts, respectively, to $29 \pm 2 \%, 7 \pm 2 \%$ and $13 \pm 2 \%$ of the haploid 168 chromosome (Table 3). For strain GSY1127, this is in good agreement with data obtained by mapping, while for strains GSY1835 and GSY1800, the calculated figures are higher than those obtained by genetic methods (Table 3 ). The latter discrepancy can be readily accounted for by the fact that linkage was obtained from crosses between markers too distant from the junctions for adequate precision. In particular, due to absence of a suitable marker, the size of segment $C$ was probably underestimated.

Inspection of Table 2 reveals that genes $p h e A$ and $d n a B$ of strain GSY1127, gene degR of strain GSY1800, and genes $b s d M, \operatorname{pur} M, \cot A$ and $s s p E$ of strain GSY1835 are present in two copies.

The anomalies obtained with $\operatorname{tr} p E$ and $\operatorname{tr} p D$ probes, i.e. apparently non-integer numbers of corresponding genes (Table 2), have their explanation in the fact that the probes were derived from strains homologous to B. subtilis 168 , while part of the trp region present in merodiploids originates from $B$. subtilis W23. Firstly, the construction of merodiploids GSY1127 and GSY1800 involves the correction of the $\operatorname{trpE26}$ mutation by a wild-type allele. The latter was derived from different 168/W23 hybrid 

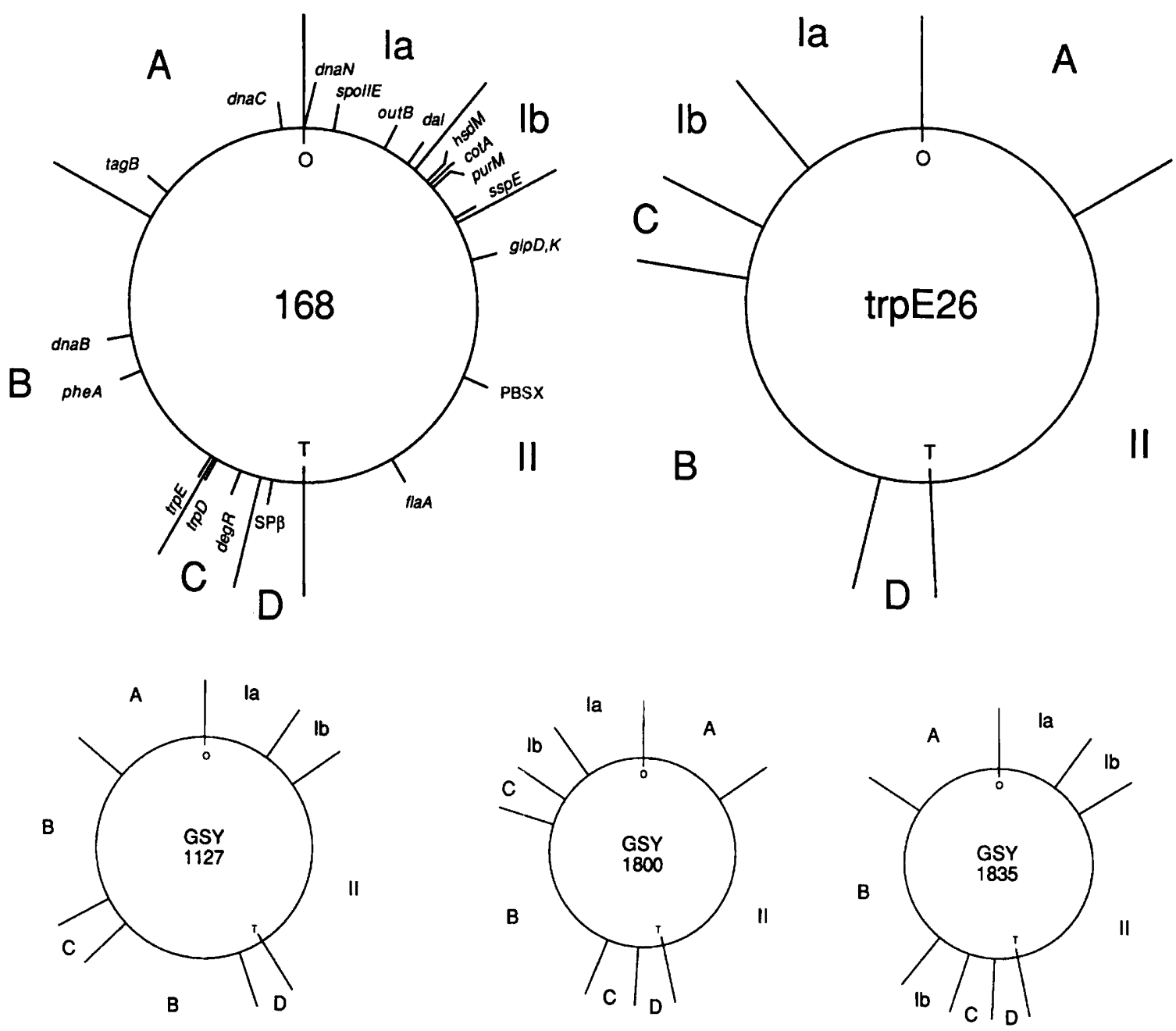

Fig. 1. Chromosomal structure of merodiploid strains GSY1127, GSY1800 and GSY1835 and their parent trpE26 and 168 type strains as revealed by genetic linkage in appropriate transformation and transduction crosses. 'trpE26 type' refers to the mutant 166 trpE26 isolated by X-ray irradiation of spores of the Marburg strain (Burkholder \& Giles, 1947), as well as to strains of 168 genetic background into which the rearrangements associated with the trpE26 mutation of strain 166 have been introduced by transformation. Letters $A$ to $D$ and roman numerals I and II indicate different segments of the chromosome. Segments B, C and Ib are duplicated in merodiploids GSY1127, GSY1800 and GSY1835, respectively. O and T are the origin and terminus of replication. Known genes probed in this work by quantitative DNA-DNA hybridization are indicated on the map of strain 168.

strains (C. Anagnostopoulos, personal communication), in which the original, strain $168, \operatorname{trp} C 2$ mutation was corrected by DNA from strain W23 (often designated 23, C. Anagnostopoulos, personal communication). This event was accompanied by replacement of part, or all, of the strain $168 \operatorname{tr} p D$ and $\operatorname{tr} p E$ genes, closely linked to $\operatorname{tr} p C$, by the analogous but heterologous region of strain $W^{\prime} 23$. Secondly, control hybridizations of 168 probes with homologous (168) and heterologous W23 DNA revealed, with the latter, a $50 \%$ reduction of hybridization counts. Thirdly, the mapping of the $\mathrm{B}-\mathrm{C}$ junction between residues 1554 and 1555 in the 1751 bp sequence of gene $\operatorname{trpE}$ (Henner et al., 1984; Jarvis et al., 1990) and the maps of relevant merodiploids (Fig. 1) suggest that in GSY1127 the major part of $\operatorname{tr} p E$ and the $\operatorname{tr} p D$ gene are present in two and one copies, respectively, while in GSY1800, the respective genes are present in one and two copies.
Therefore, since the fragment of gene trpE used as probe is localized on segment $B$, the apparently anomalous hybridization counts for the trp markers (Table 2) reveal that, of the two $\operatorname{tr} p E$ genes in GSY1127 and the two trpD genes in GSY1800, one derives from 168 and the other from W23. In addition, the high ratio of 2.30 (Table 2), i.e. the low hybridization of the probe to merodiploid DNA, shows that the single $\operatorname{trpD}$ copy in strain GSY1127 originates from W23. Preliminary evidence obtained by Southern hybridization is compatible with these conclusions. Further investigations should assess whether the heterologous nature of the trp genes, present at the junctions of the two duplicate regions, played any role in the stability of the merodiploids.

Inspection of Table 2 reveals that the target of probe $\lambda 970$, which includes part of prophage $\operatorname{SP} \beta$, is present in two 
Table 2. Quantitative DNA-DNA hybridization of specific cloned 168 markers and $B$. subtilis merodiploid strains GSY1127, 1800 and 1835

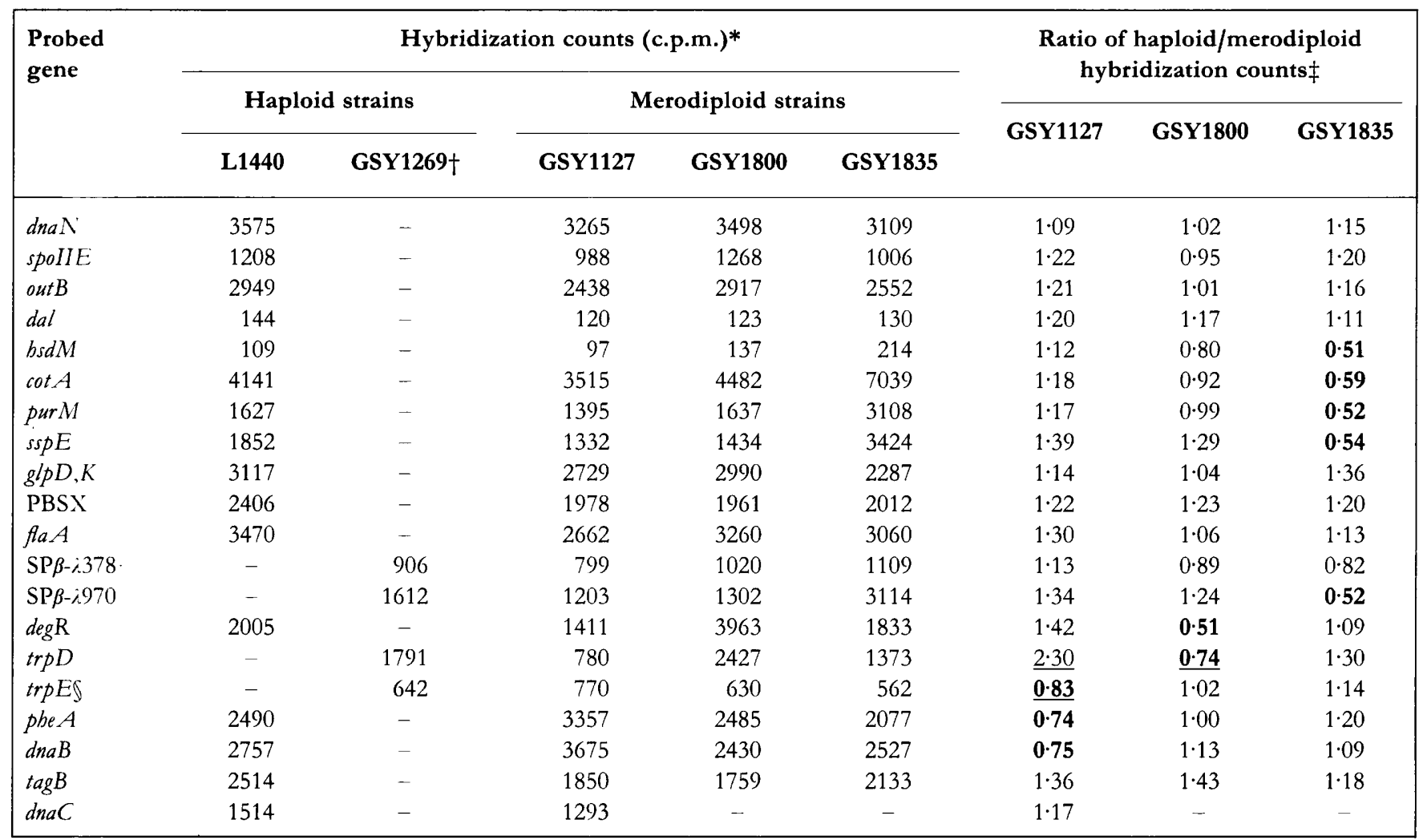

* Chromosomal DNA was extracted from stationary-phase cultures in SA medium. DNA samples of each merodiploid and reference haploid strain were adsorbed on filters. Probes were generated from cloned strain 168 chromosomal fragments. Counts obtained with the $0 \cdot 15 \mu \mathrm{g}$ DNA samples were used (see Methods). The background was between 14 and 45 c.p.m. Each figure refers to a single experiment.

f In the course of this study, it has appeared that strain L1440, the reference haploid 168 type strain, (i) is either cured of SP $\beta$ or bears a deletion at the prophage level (data not presented) and (ii) possesses $\operatorname{tr} p E$ and $\operatorname{tr} p D$ genes which originate from strain W23 (data not presented). Therefore, hybridization counts for SP $\beta$ and $\operatorname{tr} p$ markers were determined with the DNA from the haploid $\operatorname{tr} p E 26$ type strain GSY1269, which is lysogenic for SP $\beta$ and whose trp region is isogenic to that of strain 168.

$\ddagger$ Bold characters denote duplicated DNA homologous to that of the probes used. The underlined ratios correspond to $\operatorname{trp}$ probes which yielded an apparently non-integer number of copies of corresponding genes.

$\int$ The fragment of gene $\operatorname{trp} E$ used as probe belongs to segment B (see text and Fig. 1).

Table 3. Excess DNA in merodiploids as percentage $(x)$ of the haploid chromosome

The mean values of $x$ were obtained from values for genes located in the haploid as well as in the diploid regions.

\begin{tabular}{|lccc|}
\hline Method & \multicolumn{3}{c|}{ Merodiploid strain: } \\
\cline { 2 - 4 } & GSY1127 & GSY1800 & GSY1835 \\
\hline $\begin{array}{l}\text { Quantitative DNA-DNA } \\
\text { hybridization* } \\
\begin{array}{c}\text { Genetic mapping } \\
\text { (Anagnostopoulos, 1990) }\end{array}\end{array}$ & $29.0 \pm 2 \cdot 2$ & $6.7 \pm 1.9$ & $12.9 \pm 1.8$ \\
\hline
\end{tabular}

* Figures obtained from data in Table 2, with the exception of $\operatorname{trp} D$ and $\operatorname{tr} p E$ markers, as well as for the 28 randomly chosen probes (see text). The means are shown $\pm s D$. copies in the merodiploid GSY1835. Segment Ib of strain 168 includes at its extremity proximal to the origin of replication a secondary SP $\beta$ attachment site (Lipsky et al., 1981), unoccupied by a prophage. This is also true for trpE26 strains, GSY1127, GSY1800 and one of the two copies of fragment Ib of strain GSY1835 (data not presented). Therefore, the second copy of a fragment of SP $\beta$ found in the latter strain cannot but have arisen from the prophage located in segment $D$. The model for the generation of GSY1835 (Schneider \& Anagnostopoulos, 1981) proposed a recombination near prophage SP $\beta$ which could induce precisely such a translocation. Preliminary evidence in favour of the role of prophage $\mathrm{SP} \beta$ in the generation of GSY1835 has already been obtained (Schneider \& Anagnostopoulos, 1983).

In conclusion, the quantitative, physico-chemical method devised has revealed that duplicated chromosomal regions of all B. subtilis merodiploid strains examined correspond 
to additional DNA which, in strain GSY1127, is equivalent to about $30 \%$ of the chromosome. It follows that $B$. subtilis cells, with an apparently normal morphology (Hauser, 1991), can accommodate genomes of substantially increased size. Probably, the largest duplication, amounting, according to this contribution, to a total of $36 \%$ of the chromosome, is present in the unstable merodiploids designated $\mathrm{Trp}^{+}$and Ilv $\mathrm{A}^{+} \mathrm{Hom}^{+}$(Anagnostopoulos, 1990). However, strain GSY1127 grows significantly more slowly than the wild-type (Hauser, 1991) and its DNA/cell volume ratio, presently under investigation, should throw new light on the importance of this ratio for cell growth.

\section{ACKNOWLEDGEMENTS}

This contribution is dedicated to C. Anagnostopoulos for his 75th birthday. We are grateful to him for strains, fruitful discussions and critical reading of the manuscript. We thank A. Galizzi, C. Holmberg, A. Kiss, P. Longchamp, P. Margot. P. Nygaard, R. J. Roberts, P. Setlow, H. Zalkin, L. Zheng and the Bacillus Genetic Stock Center (Ohio State University) for providing recombinant plasmids and bacteriophages.

This work was submitted by P. M. Hauser as part fulfilment for a PhD degree at the University of Lausanne.

\section{REFERENCES}

Albertini, A. M., Caramori, T., Crabb, W. D., Scoffone, F. \& Galizzi, A. (1991). The fla A locus of Bacillus subtilis is part of a large operon. coding for flagellar structures, motility functions, and an ATPaselike polypeptide. J Bacteriol 173, 3573-3579.

Anagnostopoulos, C. (1977). Genetic analysis of Bacillus subtili: strains carrying chromosomal rearrangements. In Modern Trends in Bacterial Transformation and Transfection, pp. 211-230. Edited by A. Portolés, R. Lopez \& M. Espinosa. Amsterdam: Elsevier/ North Holland Biomedical Press.

Anagnostopoulos, C. (1990). Genetic rearrangements in Bacillu.i subtilis. In The Bacterial Cbromosome, pp. 361-371. Edited by M. Riley \& C. Drilica. Washington, DC: American Society for Microbiology.

Anagnostopoulos, C. \& Trowsdale, J. (1976). Production of merodiploid clones in Bacillus subtilis. In Microbiology-1976, pp. 44-57. Edited by D.'Schlessinger. Washington, DC: American Society for Microbiology.

Audit, C. \& Anagnostopoulos, C. (1972). Production of stable and persistent unstable heterogenotes in a mutant of Bacillus subtilis. In Spore $V$, pp. 117-125. Edited by H. O. Halvorson, R. Hanson \& L. L. Campbell. Washington, DC: American Society for Micro biology.

Band, L., Shimotsu, H. \& Henner, D. J. (1984). Nucleotide sequence: of the Bacillus subtilis trpE and $\operatorname{trpD}$ genes. Gene 27, 55-65.

Burkholder, P. R. \& Giles, N. H. (1947). Induced biochemical mutations in Bacillus subtilis. Am J Bot 34, 345-348.

Collins, M. E., Oultram, J. D. \& Young, M. (1985). Identification of restriction fragments from two cryptic Clostridium butyricum plasmids that promote the establishment of a replication-defective plasmid in Bacillus subtilis. J Gen Microbiol 131, 2097-2105.

Del Sal, G., Manfioletti, G. \& Schneider, C. (1988). A one-tube plasmid DNA mini-preparation suitable for sequencing. Nucleic Acids Res 16, 9878.

Donovan, W., Zheng, L., Sandman, K. \& Losick, R. (1987). Genes encoding spore coat polypeptides from Bacillus subtilis. $J$ Mol Biol 196, $1-10$.

Feinberg, A. P. \& Vogelstein, B. (1983). A technique for radiolabelling DNA restriction endonuclease fragments to high specific activity. Anal Biocbem 132, 6-13.

Ferrari, E., Henner, D. J. \& Hoch, J. A. (1981). Isolation of Bacillus subtilis genes from a Charon 4A library. $J$ Bacteriol 146, 430-432.

Ferrari, E., Henner, D. J. \& Yang, M. Y. (1985a). Isolation of an alanine racemase from Bacillus subtilis and its use for plasmid maintenance in B. subtilis. Bio/Tecbnology 3, 1003-1007.

Ferrari, E., Scoffone, F., Ciarrochi, G. \& Galizzi, A. (1985b). Molecular cloning of a Bacillus subtilis genes involved in spore outgrowth. J Gen Microbiol 131, 2831-2838.

Gianni, M. \& Galizzi, A. (1986). Isolation of genes preferentially expressed during Bacillus subtilis spore outgrowth. J Bacteriol 165, 123-132.

Grossberger, D. (1987). Minipreps of DNA from bacteriophage lambda. Nucleic Acids Res 15, 6737.

Hackett, R. H. \& Setlow, P. (1987). Cloning, nucleotide sequencing, and genetic mapping of the gene for small, acid-soluble spore protein $\gamma$ of Bacillus subtilis. J Bacteriol 169, 1985-1992.

Hauser, P. M. (1991). Etude de la structure génétique des exfusionnants de protoplastes et des souches mérodiplö̈des chez Bacillus subtilis. Thesis, University of Lausanne, Switzerland.

Hauser, P. M. \& Karamata, D. (1992). Ploidy of Bacillus subtilis protoplasts exfusants: the haploid nature of cells forming colonies with biparental and prototrophic phenotypes. J Gen Microbiol 138, 1077-1088.

Hauser, P. M., Crabb, W. D., Fiora, M. G., Scoffone, F. \& Galizzi, A. (1991). Genetic analysis of the flaA locus of Bacillus subtilis. I Bacteriol 173, 3580-3583.

Henner, D. J., Band, L. \& Shimotsu, H. (1984). Nucleotide sequence of the Bacillus subtilis tryptophan operon. Gene 34, 169-177.

Holmberg, C. \& Rutberg, B. (1989). Cloning of the glycerol kinase gene of Bacillus subtilis. FEMS Microbiol Lett 58, 151-156.

Jarvis, E. D., Cheng, S. \& Rudner, R. (1990). Genetic structure and DNA sequences at junctions involved in the rearrangements of Bacillus subtilis strains carrying the trpE26 mutation. Genetics 126, 785-797.

Karamata, D. \& Gross, J. D. (1970). Isolation and genetic analysis of temperature-sensitive mutants of $B$. subtilis defective in DNA synthesis. Mol \& Gen Genet 108, 277-287.

Kiss, A., Posfai, G., Keller, C. C., Venetianer, P. \& Roberts, R. J. (1985). Nucleotide sequence of the BsuRI restriction-modification system. Nucleic Acids Res 13, 6403-6421.

Lipsky, R. H., Rosenthal, R. \& Zahler, S. A. (1981). Defective specialized SP $\beta$ transducing bacteriophages of Bacillus subtilis that carry the sup-3 or sup-44 gene. J Bacteriol 148, 1012-1015.

Longchamp, P. (1990). Etude de l'organisation génétique du bactériophage défectif PBSX de Bacillus subtilis par mutagenèse d'insertion. Diplôme de biologiste, Université de Lausanne.

Maniatis, T., Fritsch, E. F. \& Sambrook, J. (1982). Molecular Cloning: a Laboratory Manual. Cold Spring Harbor, NY: Cold Spring Harbor Laboratory.

Marmur, J. (1961). A procedure for the isolation of deoxyribonucleic acid from microorganisms. $J$ Mol Biol 3, 208-218.

Mauël, C. \& Karamata, D. (1984). Characterisation of proteins induced by mitomycin $C$ treatment of Bacillus subtilis. J Virol 49 , 806-812.

Mauël, C., Young, M., Margot, P. \& Karamata, D. (1989). The 
essential nature of teichoic acids in Bacillus subtilis as revealed by insertional mutagenesis. Mol \& Gen Genet 215, 388-394.

Ogasawara, N., Moriya, S., Mazza, P. G. \& Yoshikawa, H. (1986). Nucleotide sequence and organisation of $d n a B$ and neighboring genes on the Bacillus subtilis chromosome. Nucleic Acids Res 14, 9989-9999.

Perego, M., Ferrari, E., Bassi, M. T., Galizzi, A. \& Mazza, P. G. (1987). Molecular cloning of Bacillus subtilis genes involved in DNA metabolism. Mol \& Gen Genet 209, 8-14.

Saxild, H. H. \& Nygaard, P. (1988). Gene-enzyme relationships of the purine biosynthetic pathway in Bacillus subtilis. Mol \& Gen Genet 211, 160-167.

Schaeffer, P., Millet, J. \& Aubert, J. P. (1965). Catabolic repression of bacterial sporulation. Proc Natl Acad Sci US A 54, 704-711.

Schneider, A.-M. \& Anagnostopoulos, C. (1981). Linkage map and properties of a Bacillus subtilis strain carrying a non-tandem duplication of the purB-tre region of the chromosome. $J$ Gen Microbiol 125, 241-256.

Schneider, A.-M. \& Anagnostopoulos, C. (1983). Bacillus subtilis strains carrying two non-tandem duplications of the $\operatorname{trp} E-i l v A$ and the purB-tre regions of the chromosome. J Gen Microbiol 129, 687-701.

Schneider, A.-M., Gaisne, M. \& Anagnostopoulos, C. (1982). Genetic structure and internal rearrangements of stable merodiploids from Bacillus subtilis strains carrying the trpE26 mutation. Genetics 101, 189-210.

Trowsdale, J. \& Anagnostopoulos, C. (1975). Evidence for the translocation of a chromosome segment in Bacillus subtilis strains carrying the trpE26 mutation. J Bacteriol 122, 886-898.

Yang, M., Shimotsu, H., Ferrari, E. \& Henner, D. J. (1987). Characterization and mapping of the Bacillus subtilis prtR gene. J Bacteriol 169, 434-437.

Young, M., Mauël, C., Margot, P. \& Karamata, D. (1989). Pseudoallelic relationship between non-homologous genes concerned with biosynthesis of polyglycerol phosphate and polyribitol phosphate teichoic acids in Bacillus subtilis strains 168 and W23. Mol Microbiol 3, 1805-1812.

Received 23 August 1993; revised 10 January 1994; accepted 18 January 1994. 